\title{
Contribution of benthic biomass to overall metabolism in New Caledonia lagoon sediments
}

\author{
Guy Boucher ${ }^{1}$, Jacques Clavier ${ }^{2}$ \\ ${ }^{1}$ UA CNRS 699, Biologie des Invertébrés marins, Muséum national d'Histoire naturelle, 55, rue de Bufíon, F-75231 Paris, \\ France \\ ${ }^{2}$ Centre ORSTOM, BPA 5, Nouméa, Nouvelle-Calédonie
}

\begin{abstract}
Granulometric parameters, benthic biomasses of living organic matter, and oxygen and nitrogen fluxes at the water-sediment interface were investigated on triplicate samples, or in dark experiments, at 12 stations in the lagoon in SW New Caledonia. Analysis of functional characteristics of 3 bottom types revealed significant differences in the benthic food-webs. Onshore muddy bottoms had the lowest respiration, related to the lowest A.TP pool and meiofauna density, in spite of high organic and pigment content. Near-reef white-sand bottoms were a sink for DON (dissolved organic nitrogen), exported no significant DIN (dissolved inorganic nitrogen), and supported the highest living biomass (ATP) via meiofauna and active microphytes. Intermediate grey-sand bottoms had the highest respiration, related to macrophyte cover and to a lesser extent to larger macrobenthos biomass, and were a source of nutrients for the water-column (DIN and DON). Partitioning of benthic biomass was investigated using non-linear multiple regression. Oxygen consumption was mainly related to ATP content, considered as representative of micro- and meiofauna biomass, then to macrophyte biomass and to a lesser extent to macrofauna biomass. Pigment content did not improve the relationship. Depletion of inorganic nitrogen efflux, when compared to high respiration rates, increased from muddy bottoms to white-sand bottoms. Organic nitrogen (DON) exchanges were an order of magnitude greater than DIN exchanges indicating a considerable nitrogen demand in the sediment.
\end{abstract}

\section{INTRODUCTION}

Most reefs achieve a high level of primary production in the face of low nutrient concentrations in the surrounding water (Lewis 1977). Different sources of nutrients have been identified: fixation of atmospheric nitrogen (Johannes et al. 1972, Wiebe et al. 1975), oceanic organic matter (Sorokin 1973), and endoupwelling (Rougerie \& Wauthy 1986). Many authors consider that coral-reef primary production is not limited by the low concentrations of nutrients in the water column due to the massive flux of water, and biological fixation and food web complexity with efficient recycling processes (Crossland \& Barnes 1983, see Wiebe 1985 for a review). Accumulation of a large biomass into a network of biotic communities, which are effective in preventing leaks to the surrounding ocean, could be the key to the success of coral reefs as biologically rich and diverse entities (Smith 1984).

Recycling processes at the water-sediment interface and the structure of benthic food-chains are however, poorly known in most lagoonal areas (see Alongi 1989 for a review). Oxygen consumption, generally accepted as a measure of heterotrophic activity in sediments, may provide the basis of an estimate of decomposition by the benthic community (Andersen \& Hargrave 1984). The present paper is a preliminary study on benthic metabolism, i.e. oxygen uptake and nitrogen exchange at the water-sediment interface, related to benthic biomass partitioning in the southwest lagoon of New Caledonia. The size of total living biomass, microphytobenthos, meiofauna and macrofauna/flora was estimated in the 3 soft bottom types defined in the lagoon (Chardy \& Clavier 1988a, Chardy et al. 1988). The interdependence between these fluxes and environmental conditions is assessed.

\section{MATERIAL AND METHODS}

Study site. Benthic habitats were defined as coastal muddy bottoms, intermediate grey-sand bottoms, and white-sand bottoms adjacent to the reef, their relative surface areas being respectively 35,50 and $15 \%$, 
throughout the South-West New Caledonia lagoon area $\left(2000 \mathrm{~km}^{2}\right)$. Their macrofauna structure was analysed on the basis of qualitative (Richer de Forges et al. 1987) and quantitative studies (Chardy \& Clavier 1988a, Chardy et al. 1988). Numerically dominant species, biomass and trophic groups of the macrofauna suggested different functional patterns related to nutrient dynamics within the 3 major benthic communities. A first attempt to estimate the carbon budget in the lagoon is proposed by Chardy \& Clavier 1988b.

During a cruise on board the OV 'Alis' in OctoberNovember 1988, 12 stations ( 6 to $16 \mathrm{~m}$ depth) were selected as representative of the different communities in the lagoon (Fig. 1). At each station, the vessel was moored fore and aft at dawn, so that enclosure experiments and benthos sampling could be undertaken before the trade-wind arose.

Incubation procedure. Oxygen and nutrient fluxes at the water-sediment interface were measured in the water trapped in enclosures according to a procedure described by Boucher \& Boucher-Rodoni (1988). The bases of 3 replicate PVC tubes ( $50 \mathrm{~cm}$ diameter; $0.2 \mathrm{~m}^{2}$ ) were pushed by SCUBA diver into the sediment at some meters distance, ensuring that a minimum of $5 \mathrm{~cm}$ was inserted vertically into the substrate, even when the coral rock was close to the water-sediment interface. The enclosures were then closed with clear acrylic hemispheres to trap a known volume of bottom water, varying from 57 to $72.5 \mathrm{l}$ according to the depth of core insertion into the substrate. Each enclosure was covered with black polyethylene plastic foil (for light isolation) and with an aluminium cover (for thermic isolation). Temperature in the surrounding water fluctuated between 24 and $25^{\circ} \mathrm{C}$. Gusher galley pumps (Whale MKIII), connected to a $12 \mathrm{~V}$ power supply on board the vessel, maintained a $12 \mathrm{l} \mathrm{min}{ }^{-1}$ closed-circuit flow rate through each enclosure, allowing good mixing without noticeable particulate resuspension. A calibrated polarographic electrode connected to the surface was placed in each dome for continuous oxygen recording ( 2 Yellow Spring Instruments and one Orbisphere 2609 oxymeter)

The incubations were started early in the morning and lasted 2 to $3 \mathrm{~h}$, a duration allowing significant changes in nutrient concentrations in the trapped water without critical oxygen depletion (not lower than $80 \%$ saturation). Samples for nutrient analyses were withdrawn by SCUBA diving every $30 \mathrm{~min}$, from To to T6 for $3 \mathrm{~h}$ incubations, with $60 \mathrm{ml}$ syringes. Outside water was admitted through a port during sampling to avoid interstitial water release from the sediment. Some control experiments were performed in the after-

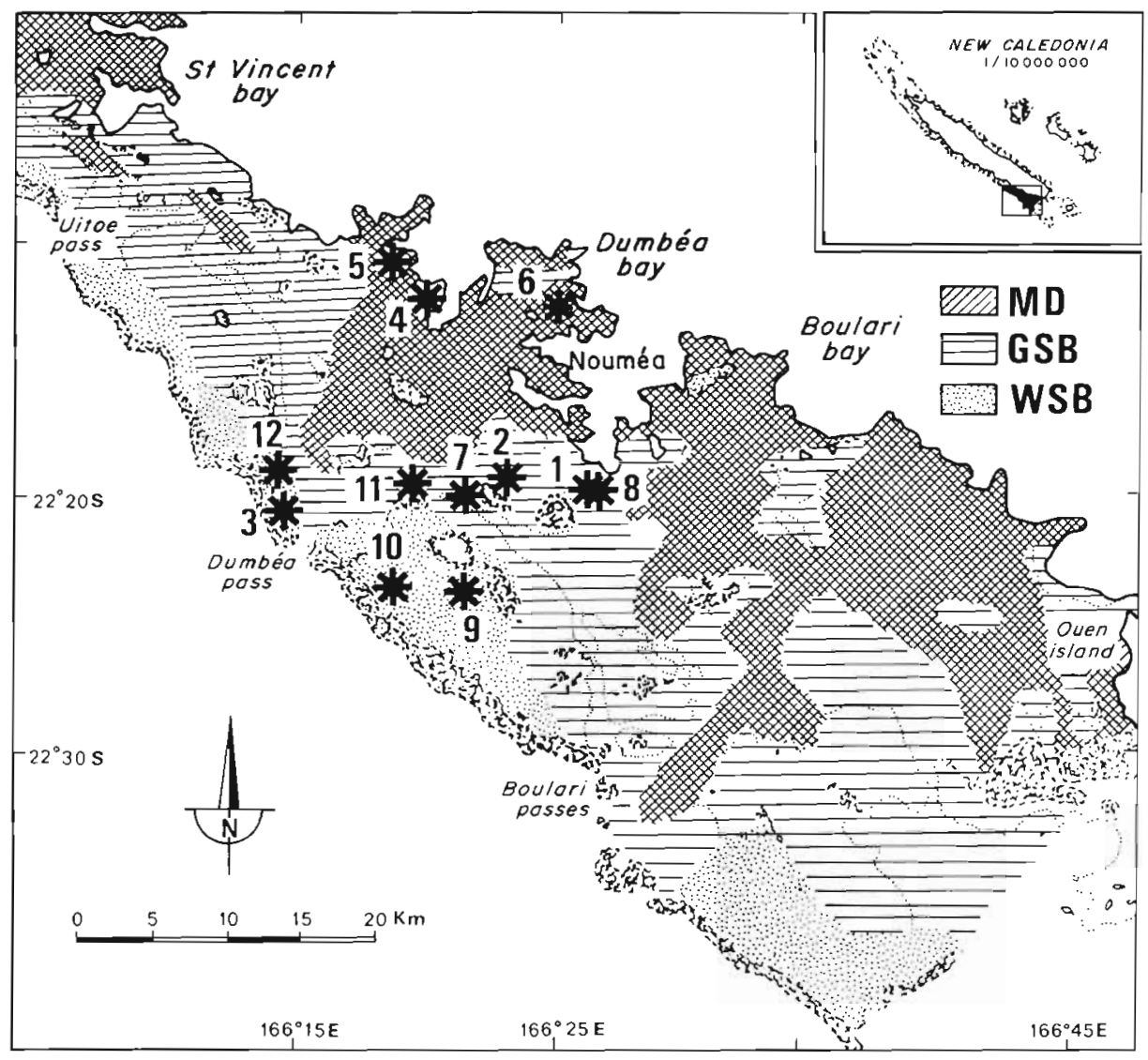

Fig. 1. Location and depth (Z) of 12 sampling sites in SW New Caledonia lagoon off Nouméa. Muddy bottoms (MD): 4 = 'Baie Maa' $(Z=12 \mathrm{~m}), 5=$ 'Baie Papaye' $(Z=13 \mathrm{~m}), 6=$ 'Ilôt Freycinet' $(Z=9 \mathrm{~m})$; grey-sand bottoms (GSB): 1 \& $8=$ 'Rocher' à la Voile $1 \& 2$ ' $(Z=9 \& 10 \mathrm{~m}), 2$ \& $7=$ 'Sèche Croissant $1 \& 2^{\prime}(Z=$ $10 \& 13 \mathrm{~m}), 11=$ 'La Régnère' $(\mathrm{Z}$ $=15 \mathrm{~m})$; white-sand bottoms (WSB): $3 \& 12=$ Récif M'Béré 1 \& $2(\mathrm{Z}=6$ \& $12 \mathrm{~m}), 9=$ 'Ilôt Goéland' $(Z=11 \mathrm{~m}), 10=$ 'Grand Récif Aboré' $(Z=16 \mathrm{~m})$ 
noon to assess planktonic contributions to the changes of nutrient and oxygen concentrations in the volume of the enclosure isolated from the sediment by a watertight PVC plate at the interface level.

Ammonium, nitrate + nitrite (DlN), and dissolved organic nitrogen (DON) were immediately analysed on board by Technicon Industrial methods using respectively the indo-phenol blue method (Solorzano 1969), the Treguer \& Lecorre (1975) method, and the UV oxidation method (Armstrong \& Tibbits 1968). The efficiency of photoxidation was controlled by urea mineralization $(6 \mathrm{~h})$, which gave 95 and $83 \%$ efficiencies for concentrations lower than 12 and 20 umol $1^{-1}$, respectively. For each enclosure, the rate of change in nutrient concentration ( $\mu \mathrm{mol} \mathrm{N} \mathrm{I}^{-1}$ ) was calculated by linear regression of the 4 to 7 measures, corrected for water volume trapped in the enclosure and for bottom surface area ( $u m o l \mathrm{~N} \mathrm{~m}^{-2} \mathrm{~h}^{-1}$ ). Linear change of oxygen concentration ( $\mathrm{mg} \mathrm{l}^{-1}$ ) allowed calculation of oxygen consumption expressed as mg $\mathrm{O}_{2} \mathrm{~m}^{-2} \mathrm{~h}^{-1}$ or converted to carbon assuming $\mathrm{RQ}=1$. Dilution caused by compensation of water withdrawal was assumed to be negligible.

Processing of the samples. At the end of each triplicate incubation, various samples were collected to characterize the sediment. From 4 to 6 cores were taken to a depth of $4 \mathrm{~cm}$ depth outside the enclosures and mixed for granulometric analyses [including silt content $<63 \mu \mathrm{m}$, median $=$ phi 50 , mean grain size $=$ $($ phi $16+$ phi $50+$ phi 84$) / 3$, quartile deviation $=($ phi 75-phi 25)/2, inclusive graphic quartile deviation = (phi 84-phi 16)/4 + (phi 95-phi 5)/6.6]. Inside each enclosure, triplicate sediment syringe-cores of $5.31 \mathrm{~cm}^{2}$ and $4 \mathrm{~cm}$ depth were taken for water content (expressed as \% weight loss at $60^{\circ} \mathrm{C}$ ); organic matter content measured by weight loss at $550^{\circ} \mathrm{C}$ (expressed as $\%$ dry weight or $\mathrm{mg} \mathrm{m}^{-2}$; AFDW: ash free dry weight); and total pigments, chlorophyll a and phaeophytin (expressed as $\mathrm{mg} \mathrm{m}^{-2}$ ) extracted from the sediment in methanol $98 \%$ (Holm-Hansen \& Rieman 1978) and measured by the fluorimetric method after deep-freezing and lyophylisation. Adenosine nucleotides (ATP: expressed as $\mathrm{ng} \mathrm{cm}^{-2}$ ) were determined on triplicate $5.31 \mathrm{ml}$ samples from the top $\mathrm{cm}$ of sediment. Extraction was achieved with $10 \mathrm{ml}$ boiling $\mathrm{NaHCO}_{3}$ (Bancroft et al. 1966) immediately on board ship, and the extract was deep-frozen for later analysis by the bioluminescence method (Charpy-Roubaud 1986). Meiobenthos density was measured on triplicate cores (10 $\mathrm{cm}^{2}$ to $5 \mathrm{~cm}$ depth) collected near each enclosure. Sediment was stained with Rose Bengal, sieved on 2 mesh sizes ( 250 and $40 \mu \mathrm{m}$ ) and centrifuged 4 times by Ludox TM method. The $40 \mu \mathrm{m}$ fraction was diluted $(1 / 4$ to $1 / 16$ ) with a subsampler box to sort at least 100 nematodes and associated taxa. Density (expressed as number per $10 \mathrm{~cm}^{2}$ ) was obtained by summing counts in the $250 \mu \mathrm{m}$ fraction and counts $\times$ dilution in the $40 \mu \mathrm{m}$ fraction. Macrobenthos (macrofauna and macroflora) present in the enclosure was collected down to the hard ground when present or down to $20 \mathrm{~cm}$ depth, using an air-sucker with a $1 \mathrm{~mm}$ sieve net. Species composition and total biomass $\left(\mathrm{g} \mathrm{m}^{-2}\right.$ AFDW) were analysed in the laboratory after fixation (10\% formalin), dessication at $60^{\circ} \mathrm{C}$, and ash content determination at $550^{\circ} \mathrm{C}$.

Statistical treatment of data. One-way analysis of variance (ANOVA) was performed on each parameter between 3 bottom types (1: muddy bottoms: 2: greysand bottoms; 3: white-sand bottoms) after testing equality of variance (Bartlett test) and normality of the data at $\mathrm{p}<0.05$ level (Kolmogorov-Smirnov test). When these conditions were not fulfilled, non-parametric Kruskal-Wallis 1-way ANOVA was used to test sample homogeneity.

The measured metabolic activities are the sum of a number of different processes occurring in the sediment. Oxygen uptake was related to primary variables, i.e. biomasses considered separately as ATP (living biomass including bacteria, microbenthos and microphytobenthos estimated by chlorophyll a content, meiobenthos), macroflora and macrofauna. The other descriptors are considered secondary variables. Although modifying the values of primary variables in the 3 different bottoms, they have only indirect influence on respiration when the chemical oxygen demand is excluded. Since metabolic activities of 2 or more component species (Pamatmat \& Findlay 1983) or compartments (Boucher-Rodoni \& Boucher in press) measured together do not equal the sum of their separate metabolism, respiration had to be expressed as a nonlinear power relation (Banse et al. 1971, Banse 1982, Pomroy et al. 1983):

$$
\mathrm{R}=\sum a_{i} \cdot \mathrm{W}_{i}^{b_{1}}+k
$$

where $\mathrm{R}=$ oxygen flux (oxygen uptake of undisturbed sediment with its fauna and flora); $W=$ benthic biomass; $k=$ a constant; $i=$ number of independent variables; $a$ and $b=$ physiological constants.

This equation was computed using a generalisation of a non-linear simple regression and least squares method which minimized the quadratic error, i.e. the sum of square distances between the data and a surface, instead of a curve (Hartley 1961, Lawton \& Sylvestre 1971). This surface was defined in a plane with $i$ dimensions. In the equation, $a_{1}$ corresponds to the linear parameters characterizing the lagoon (values depending on the biomass units); $b_{i}$ represented nonlinear parameters corresponding to physiological constants of faunistic compartments. For macrofauna, a value of $b=0.74$ (Banse 1982) is accepted in the 
literature (Pomroy et al. 1983, Gerlach et al. 1985). The regression was calculated using units of $\mathrm{ng}$ ATP $\mathrm{cm}^{-2}$ and $\mathrm{g}$ macrobenthos $\mathrm{m}^{-2}$, and setting $b$ at a fixed value of 0.74 which helped to set the model.

\section{RESULTS}

Raw data including grain size, benthic parameters and flux measurements have been published for each station (36 experiments) in Clavier et al. (in press).

\section{Sediment parameters}

Twelve very fine-sand to medium-sand sublittoral stations were investigated in 3 bottom types (Fig. 1). The 3 siltiest nearshore stations $(4,5,6)$ had fine-sand sediments considered typical of muddy bottom communities. Although Chardy et al. (1988) showed that silt content above $15 \%$ has to be chosen as the main granulometric criterion for characterization of muddy bottoms, Stn 6 (11.4\% silt content) was grouped with the muddy bottoms because of its similar species composition. Coastal muddy bottoms were characterized by significantly higher mean silt content, as well as higher interstitial water content, higher quartile deviation (poorly sorted [Stns 4 and 5] to well-sorted [Stn 6]), higher inclusive graphic quartile deviation (very poorly sorted to poorly sorted), than both grey-sand and white-sand bottom values. Means were significantly different at $\mathrm{p}<0.05$ by ANOVA (Table 1).

For most grain size parameters, except mean grain size, intermediate grey-sand bottom (5-fine sand stations) and near-reef white-sand bottom (4 very finesand to medium-sand stations) sediments were not significantly different from each other (Table 1). Their distance from the barrier reef, colour and macrophyte cover however allowed an easy distinction between the 2 biotopes (Chardy \& Clavier 1988a).

Organic matter content, expressed as a dry weight percentage, was significantly different in each bottom type (Table 1). Expressed as dry wt $\mathrm{m}^{-2}$, only muddy bottom sediment organic content was significantly higher than both white- and grey-sand content.

\section{Biomass of benthic flora and fauna}

ATP content was considered as a global measure of living biomass, i.e. bacteria, microflora/fauna and meiofauna biomass, excluding macrofauna which was not sampled in small core replicates. Thirty measurements varied over an order of magnitude, ranging from 144 to $1797 \mathrm{ng}$ ATP $\mathrm{cm}^{-2}$. Mean values were significantly lower in muddy than in white-sand and greysand bottoms (Table 2). Mean chlorophyll a and phaeopigment content was significantly lower in white-sand bottoms than in grey-sand and muddysand bottoms. However, when the chl a/phaeo ratio was considered as an index of primary production, some white-sand bottom stations were revealed to be far more productive (Récif M'Béré 1 and 2: 4.6/7.6 and $12.6 / 18.5$ respectively) than both other bottom types. Meiofauna densities ranged from 440 to 10085 ind. $10 \mathrm{~cm}^{-2}$, the dominant group being the nematodes $(234$

Table 1. Mean \pm SE of sediment parameters in the 3 bottom types of SW New Caledonia lagoon: muddy bottom, grey-sand bottom, white-sand bottom. Org. matter: organic matter content $\left(\mathrm{g} \mathrm{m}^{-2}\right)_{\text {i }}$ Porosity: insterstitial water content (\%); Silt: silt content $(\%)$; Median: phi-value corresponding to the $50 \%$ point of the cumulative scale (phi $=-\log _{2}$ mesh size in mm); Mean: graphic mean diameter; $Q D$ : quartile deviation; $Q D I$ : inclusive graphic quartile deviation. Underlined values are significantly different from the others, at $p<0.05$ level, by 1 -way analysis of variance

\begin{tabular}{|lccccccc}
\hline Bottom & Org. matter & Porosity & Silt & Median & Mean & QD & QDI \\
\hline Muddy & $\underline{2602 \pm 86}$ & $\underline{47.9 \pm 1.4}$ & $\underline{22.7 \pm 4.9}$ & $1.59 \pm 0.45$ & $1.45 \pm 0.21$ & $\frac{2.22 \pm 0.15}{1.40 \pm 0.13}$ & $\frac{1.60 \pm 0.23}{0.87 \pm 0.20}$ \\
Grey-sand & $\underline{1875 \pm 75}$ & $\underline{40.7 \pm 1.2}$ & $5.8 \pm 4.2$ & $1.48 \pm 0.18$ & $1.30 \pm 0.18$ & $1.12 \pm 0.13$ & $0.74 \pm 0.20$ \\
White-sand & $\underline{2241 \pm 75}$ & $40.9 \pm 1.2$ & $3.2 \pm 4.2$ & $1.41 \pm 0.39$ & $\underline{0.80 \pm 0.18}$ & \\
\hline
\end{tabular}

Table 2. Mean $\pm \mathrm{SE}$ of benthic biomasses in the 3 bottom types. ATP: adenosine triphosphate content $\left(\mathrm{ng} \mathrm{cm}^{-2}\right)_{i} \mathrm{Chloro:}$ chlorophyll a ( $\mathrm{mg} \mathrm{m}^{-2}$ ); Phaeo: phaeopigments $\left(\mathrm{mg} \mathrm{m}^{-2}\right)$; Chl a/phaeo: pigment ratio; Meiofauna: meiofauna density (ind 10 $\mathrm{cm}^{-2}$ ): Macrofauna: macrofauna biomass ( $\mathrm{g} \mathrm{m}^{-2}$ AFDW); Macroflora: macroflora biomass ( $\mathrm{g} \mathrm{m}^{-2}$ AFDW). Underlined values are significantly different from the others, at $p<0.05$ level, by 1 -way analysis of variance

\begin{tabular}{|lccccccc|}
\hline Bottom & ATP & Chloro & Phaeo & Chl a/pheo & Meiofauna & Macrofauna & Macroflora \\
\hline Muddy & $\underline{398 \pm 68}$ & $171 \pm 15$ & $224 \pm 20$ & $3.33 \pm 1.12$ & $1224 \pm 520$ & $0.80 \pm 0.35$ & $0.79 \pm 0.91$ \\
Grey-sand & $744 \pm 72$ & $164 \pm 17$ & $212 \pm 21$ & $3.47 \pm 0.97$ & $1732 \pm 450$ & $\underline{1.57 \pm 0.30}$ & $\underline{6.47 \pm 0.79}$ \\
White-sand & $835 \pm 125$ & $\underline{134 \pm 13}$ & $\underline{162 \pm 16}$ & $\underline{\underline{7.13 \pm 0.97}}$ & $\underline{3239 \pm 450}$ & $0.87 \pm 0.30$ & 0.00 \\
\hline
\end{tabular}


Table 3. Mean $\pm \mathrm{SE}$ of bottom oxygen uptake $\left(\mathrm{mg} \mathrm{O}_{2} \mathrm{~m}^{-2} \mathrm{~h}^{-1}\right)$, carbon equivalents $\left(\mathrm{gC} \mathrm{m}^{-2} \mathrm{~d}^{-1}\right.$ ) and nitrogen flux ( $\mu \mathrm{mol} \mathrm{m}^{-2} \mathrm{~h}-1$ at the water-sediment interface in the 3 bottom types. Underlined values are significantly different from the others, at $p<0.05$ level, by 1 -way analysis of variance

\begin{tabular}{|lcrrrr|}
\hline Bottom & Respiration & Carbon equiv. & $\mathrm{NH}_{4}$ flux & NO $_{3}$ flux & DON flux \\
\hline Muddy & $\underline{38.57 \pm 4.05}$ & $\underline{0.36 \pm 0.04}$ & $27.5+4.1$ & $0.43 \pm 1.76$ & $-123 \pm 246$ \\
Grey-sand & $\underline{80.16 \pm 3.28}$ & $\underline{\underline{0.74 \pm 0.03}}$ & $30.3+3.5$ & $0.43 \pm 1.76$ & $48 \pm 188$ \\
White-sand & $\underline{\underline{6.30 \pm 5.46}}$ & $\underline{\underline{0.57 \pm 0.05}}$ & $\underline{6.8 \pm 4.1}$ & $-3.23 \pm 1.59$ & $-196 \pm 206$ \\
\hline
\end{tabular}

to 3952 ind. $10 \mathrm{~cm}^{-2}$ ). Meiofauna and nematode densities were significantly higher in white-sand than in grey-sand bottoms and muddy bottoms. The nematode proportion ranged from 24.1 to $68.9 \%$ of the total meiofauna. Macrofauna biomass was significantly higher in grey-sand than in white-sand and muddy bottoms. Macroflora biomass (macrophytes and algae) was significantly higher in grey-sand bottoms.

\section{Fluxes at the interface}

Oxygen consumption was perfectly linear during the course of each incubation and the slopes were all highly significant. Variance analysis performed on 35 incubations (one experiment failed) demonstrated that no significant differences could be detected within the 3 replicate enclosures and that values of mean oxygen consumption by the 3 different bottoms were significantly $(\mathrm{p}<0.05$ ) different from each other (Table 3). Grey-sand bottoms displayed the highest oxygen consumption, followed by white-sand bottoms and finally muddy bottoms.

Ammonium flux experiments were taken into account when the regression of the slope was significant at $p<0.05$ (27 experiments). Changes of ammonia concentration in other experiments were erratic. Effluxes were related to the 3 bottom types, increasing from white-sand to muddy and grey-sand bottoms. Nitrate fluxes were very low and erratic, and not significantly different from one community to the other. Such was also the case for DON exchanges, although the rates were much higher. Muddy bottoms and white-sand bottoms generally consumed the organic nitrogen available in the water-column. Grey-sand bottoms exported dissolved organic matter in the watercolumn. Exchanges were however erratic according to the stations as indicated by high standard error of the mean (Table 3).

\section{Correlation between parameters}

Key parameters of the benthic food-web were idenlified by Spearman rank correlation (Fig. 2). Oxygen flux ( $\mathrm{R}=$ bottom uptake) in the dark was correlated with many primary and secondary variables, and decreased with increasing silt content, organic matter content and porosity. Regression of oxygen flux on silt or water content showed a highly significant decrease of bottom uptake with both parameters (Fig. 3). Oxygen flux was also highly correlated with ATP, meiofauna densities, macrofauna and macroflora biomasses (Fig. 2). Regression of oxygen flux on meiofauna density was however only slightly significant due to higher variability of oxygen flux in greysand bottom (Fig. 4). Higher macrophyte biomass in

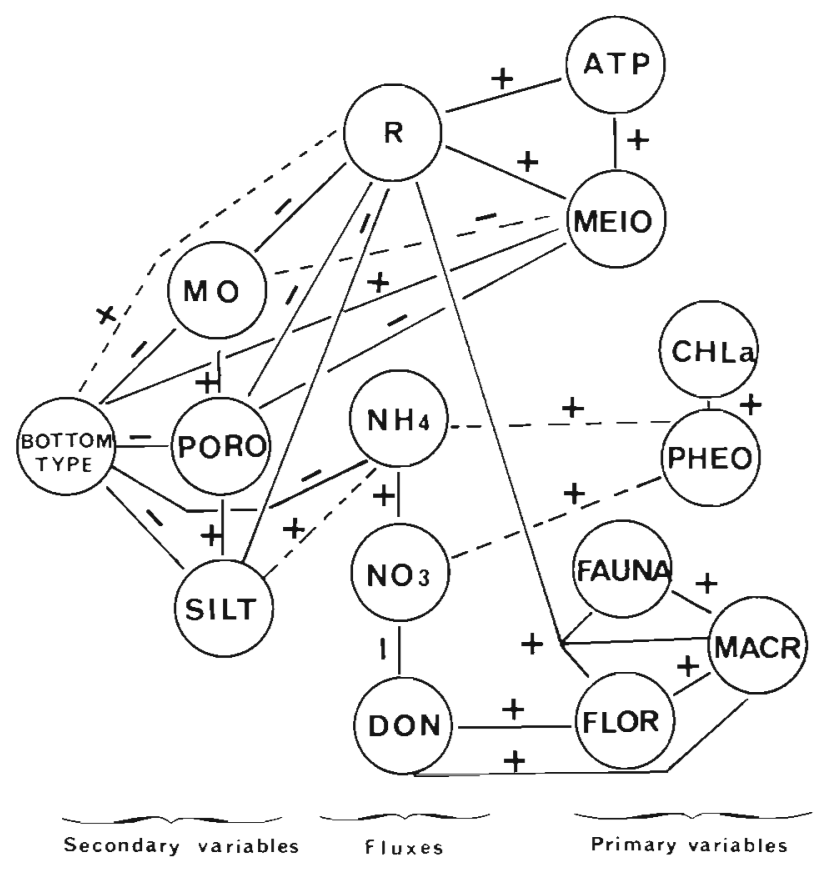

Fig. 2. Spearman rank correlations between sediment parameters, benthic biomass and fluxes at the water-sediment interface. Solid and dashed lines indicate correlation coefficient significant at $\mathrm{p}<0.05$ and $\mathrm{p}<0.001$ respectively. Fluxes: $\mathrm{R}=$ oxygen bottom uptake; $\mathrm{NH}_{4}=\mathrm{NH}_{4}$ flux; $\mathrm{NO}_{3}=\mathrm{NO}_{3}+$ $\mathrm{NO}_{2}$ flux; $\mathrm{DON}=$ dissolved organic nitrogen flux. Primary variables: $\mathrm{ATP}=$ adenosine triphosphate pool (living organic matter); Meio $=$ meiobenthos density; Chla $=$ chlorophyll a content; Pheo $=$ phaeophytin content; $\mathrm{MACR}=$ total macrobenthos biomass; FAUNA = macrofauna biomass; FLOR = macroflora biomass. Secondary variables: BOTTOM TYPE $=$ bottom types; $\mathrm{MO}=$ organic matter; $\mathrm{PORO}=$ interstitial water content; SILT $=$ silt content 


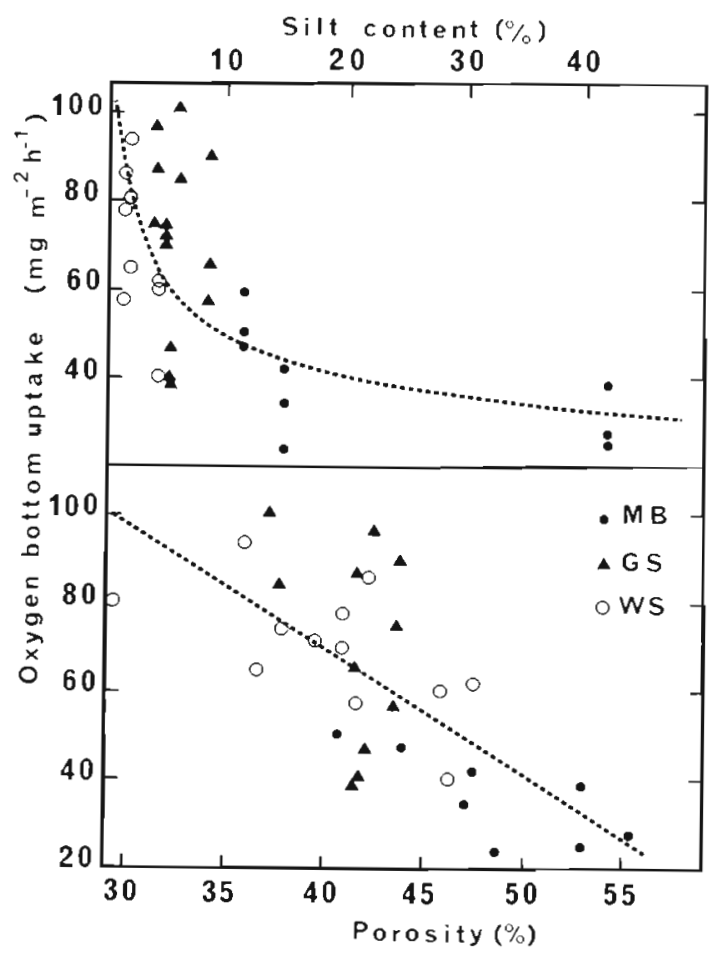

Fig. 3. Linear regression of oxygen bottom uptake on silt content (multiplicative model: $\mathrm{r}=-0.69 ; \mathrm{n}=32$; significant at $p<0.001$ ) and on porosity (simple regression: $r=-0.68 ; n=$ 32 ; significant at $\mathrm{p}<0.001$ )

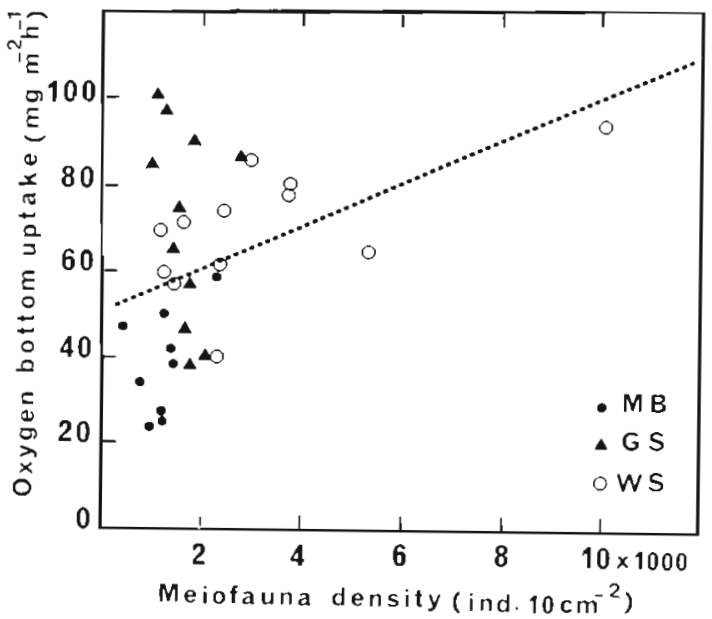

Fig. 4. Linear regression of oxygen bottom uptake on meiofauna density $(r=0.39 ; n=32$; significant at $p<0.05$ )

Stns Sèche Croissant 1 and 2 corresponded to overestimated total bottom uptake. When the meiofauna outlier at 10085 ind $10 \mathrm{~cm}^{-2}$ was omitted, the relationship was no longer significant. The ATP pool could represent a good estimation of the small benthic food-web compartment as it was the parameter best correlated with meiofauna densities. Regression of ATP pool on meiofauna density was highly significant even when the meiofauna outlier at 10085 ind $10 \mathrm{~cm}^{-2}$ was omitted (Fig. 5). No significant relation was observed with pigment content and nitrogen fluxes. However, the ratio chl a/phaeo, considered an index of active primary production, was highly correlated with bottom types and related parameters (silt, organic matter and water content) and to a lesser extent to meiofauna densities and oxygen flux.

When the different bottom types were considered separately, different relationships appeared for some parameters. Oxygen flux was no longer related to macrofauna biomass in white-sand bottoms suggesting the ATP content or meiofauna were the key parameter of benthic metabolism in such a biotope. On the other hand, ATP content decreased significantly with increasing pigment content in muddy bottoms suggesting that something in phytodetritus from adjacent mangrove might inhibit living biomass.

\section{Partitioning oxygen uplake}

Biomass independence of ATP, macrofauna, and macroflora was tested for 29 experiments as a preliminary condition for using multiple regression. Correlations of ATP with macroflora and macrofauna were not significant, but macrofauna was correlated with macroflora (at $p<0.02)$. This relation can be considered as indirect as the absence of grazers associated with macroflora has previously been demonstrated (Chardy \& Clavier 1988).

Values of the different parameters are given in Table 4. The equation for respiration, using original biomass units, can be expressed as:

$\mathrm{R}=0.26 \mathrm{ATP}^{0.77}+7.08$ Flor $\mathrm{a}^{0.60}+3.92$ Fauna $^{074}+11.21$

Introduction of chlorophyll into the model did not modify the relationship $\left(a=10^{-38}\right)$ and suggested that this

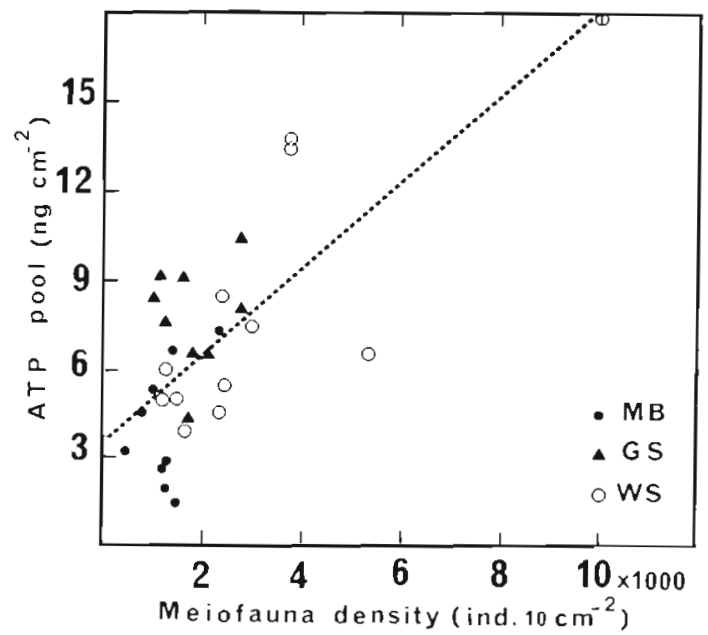

Fig. 5. Linear regression of ATP pool on meiofauna density $(\mathrm{r}=0.73 ; \mathrm{n}=30 ;$ highly significant at $\mathrm{p}<0.001)$ 
Table 4. Values of linear parameters $(a \pm S E)$, non-linear parameters $(b \pm S E$ ) and constant $k$ calculated by non-linear regressions

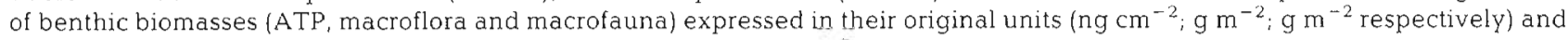
in $\mathrm{g} \mathrm{C} \mathrm{m}^{-2}$

\begin{tabular}{|lcrrrrr}
\hline Parameters & Units & ATP & Macroflora & Macrofauna & Constant \\
\hline \multirow{2}{*}{ Linear: $a(\mathrm{SE})$} & Original & $0.26(0.04)$ & $7.08(1.66)$ & $3.92(3.38)$ & $11.21(6.44)$ \\
& (g C m $\left.{ }^{-2}\right)$ & $31.17(4.33)$ & $12.26(2.87)$ & $7.33(6.67)$ & $11.23(6.44)$ \\
Non-linear: $b$ (SE) & Both & $0.77(0.39)$ & $0.60(0.39)$ & 0.74 fixed & \\
\hline
\end{tabular}

parameter was included in ATP content. Choice of $b$ values for macrofauna ranging from 0.73 to $0.78 \mathrm{did}$ not affect the values of the a constant and only slightly changed $b$ values for ATP and macroflora. Calculated $b=0.77$ for ATP was similar to the value of 0.76 found by Banse (1982) for unicellular eucaryotes and nematodes.

Using the same biomass units for each compartment $\left(\mathrm{g} \mathrm{C} \mathrm{m}^{-2}\right)$, a carbon/ATP ratio $=200(\mathrm{Karl} \&$ Larock 1975) and a carbon/biomass AFDW $=0.40$ (Steele 1974), the linear transformation did not affect the nonlinear parameters $(b)$, but demonstrated higher values of linear parameters a for ATP than for macroflora and macrofauna. Oxygen flux depended mainly on bacteria, micro- and meiobenthos biomass (ATP), and to a lesser extent on macroflora and even less on macrofauna whose contribution was erratic, as shown by high standard error of the coefficient. The constant $k$ remained similar after linear transformation (same units) and might be related to chemical oxygen demand of the sediment, a value corresponding to $17 \%$ of the mean bottom oxygen uptake $163 \mathrm{mg} \mathrm{m}^{-2}$ $\mathrm{h}^{-1}$ ), in the upper range of previous studies (Smith 1971: 5 to $9 \%$; Kemp \& Boyton 1981: 0 to $15 \%$ ).

The non-linear multiple regression between biomass and ammonia flux was not tested since regulation of ammonia efflux whatever the benthos excretion (Boucher-Rodoni \& Boucher in press) and microphytobenthos uptake are known to occur at the water-sediment interface.

\section{DISCUSSION}

The present results, based on undisturbed community metabolic activities, confirm the characterization of the communities on the basis of biomass weight and trophic groups (Chardy \& Clavier 1988a, Chardy et al. 1988). Different functional patterns are suggested within the previously identified assemblages.

The nearshore muddy bottoms are characterized by lower meio- and macrofauna benthic biomass than in the grey- and white-sand bottoms, confirmed by reduced ATP pool and oxygen bottom uptake, and indicating a paradoxically decreased biological activity with increasing silt and interstitial water content. In temperate sediments, surface increase related to decreasing particle size was thought to stimulate colonization of larger bacteria numbers (Jansson 1967 , Dale 1974) and to support larger meiofauna densities (Heip et al. 1985). Dark oxygen uptake was also known to be higher in muddy sediments than in sands from most temperate shallow water environments (Nowicki \& Nixon 1985). Two potential causes of reduced biological activity can be suggested: a negative impact of adjacent mangrove or/and an accumulation of heavy metals. Accumulation of phytodetritus produced by the mangrove system and/or by the grey-sand bottoms is suggested by higher pigment content and lower chl a/ phaeo ratio in the substrate indicating less active microalgal populations. Recent investigations in coastal silty sediments from the east coast of Australia have demonstrated a negative effect of mangrove-derived tannins associated with phytodetritus on nematode population size and macrofauna (Alongi 1987; see Alongi 1989 for a review). A second cause of benthic biomass depletion could be the accumulation of heavy metal (Ni) in coastal muddy bottoms by the effect of runoff from mining areas (Brown 1987).

Low DIN release and strong DON uptake at the interface can however be attributed to the demand of efficient microbial populations. Bacteria acting as very efficient interceptors of nutrient efflux from the sediment are known to prevent their export from mangrove sediments to adjacent waters (Alongi 1988, Boto et al. 1989) and even could import supplemental dissolved organic nutrients from the overlying water (Alongi 1989).

In white-sand bottoms, mean ATP pool and meiofauna densities were about twice the values recorded in muddy bottoms. A larger microbialmeiofauna loop should mineralize larger quantities of organic matter, reducing energy transfer to the other deposit-feeders. Macrofauna surface deposit-feeders however prevail in such biotopes (Chardy \& Clavier 1988a), suggesting that both compartments do not compete for the same trophic resources and/or that the microbial-meiofauna compartment is consumed by deposit-feeders. Insignificant ammonium efflux, and enhanced $\mathrm{NO}_{3}$ and DON uptakes from the water- 
column confirm high nutrient demand at the interface resulting from a productive microphytobenthos community rather than from bacterial populations which are known to be less productive in clean sand than in muddy substrates (Alongi 1989). In most lagoons, these near-reef sediments are a sink receiving copious quantities of organic and inorganic detritus broken away from the high energy areas of the reef front (Marshall 1965).

The grey-sand bottoms are a source of enrichment for the water column, releasing ammonium, nitrate, DON, and macroflora detritus in the absence of grazers (Chardy \& Clavier 1988a). Higher oxygen uptake was related to macrobenthos and particularly to macroflora respiration. Global dissolved nitrogen export to the water-column (DIN + DON $\left.=79 \mu \mathrm{mol} \mathrm{N} \mathrm{m}^{-2} \mathrm{~h}^{-1}\right)$, and low organic content in the sediment, confirm that only weak accumulation occurred in grey-sand bottoms. Modelling of water circulation in the SW New Caledonia lagoon is presently in progress and should quantify these transfers (Douillet pers. comm.). In a shallower lagoon from Great Barrier Reef, the considerable excess production of algal and seagrass mat material in the back lagoon is known to be exported by sharp reversals in the current direction near the passes and in coastal channels (Kinsey 1985).

Overall sediment metabolism can be determined in terms of oxygen uptake and ATP pool (Holm-Hansen \& Pearl 1972, Pamatmat 1977). To partition the contribution of benthic biomass to overall metabolism, at least 3 additional compartments should be considered in addition to macroflora and fauna in marine sediments, namely detritus, microbial biomass and meiofaunal biomass. In a tropical environment, the efficient mineralization produces mostly refractive organic material and the accumulation of significantly different quantities of organic matter among the bottom types should not affect the metabolism. In this study, only bacteria, micro-and meiofauna can be approximatively estimated by ATP content as macroflora/fauna were not sampled in small-core replicates. Meiofauna probably represent the main source of ATP, nematodes accounting for the bulk of the total sediment ATP (Sikora et al. 1977). Future investigations have to focus on nematode production, particularly in white-sand bottoms.

In white-sand, grey-sand and silty-sand bottoms, oxygen uptake corresponded to $0.74 \pm 0.03,0.57 \pm$ $0.05,0.36 \pm 0.04 \mathrm{~g} \mathrm{C} \mathrm{m}^{-2} \mathrm{~d}^{-1}$ respectively, values in the range of previous enclosure experiments performed in tropical lagoons (see Alongi 1989 for review). In. French Polynesia, Sournia (1976) found a mean hourly respiration of $58 \mathrm{mg} \mathrm{O}_{2} \mathrm{~m}^{-2} \mathrm{~h}^{-1}$, corresponding to $0.53 \mathrm{~g} \mathrm{C} \mathrm{m}^{-2}$ $\mathrm{d}^{-1}$, in shallow carbonate sands from the Moorea fringing reef. In Davies Reef (Great Barrier Reef), Kinsey
(1985) reported similar enclosure measurements of the MECOR Team ranging from 0.25 to $0.9 \mathrm{~g} \mathrm{C} \mathrm{m}^{-2} \mathrm{~d}^{-1}$. However, open-water oxygen anomaly measurements performed on the same area, including algal and coral metabolism, reached far higher rates $(3.6$ to $10.8 \mathrm{~g} \mathrm{C}$ $\mathrm{m}^{-2} \mathrm{~d}^{-1}$ ), ca 12 to 14 times the bare-sand oxygen uptake. Taking into account such differences between hard and soft bottoms, the influence of sediment oxygen uptake should still prevail on whole lagoon oxygen flux, in an area such as the NW New Caledonia lagoon where soft bottoms represent ca $80 \%$ surface.

Since Redfield (1934) first studied the ratios between oxygen uptake and nitrogen release, it has been shown that the average $\mathrm{O} / \mathrm{N}=13$ to 16 is applicable to aerobic regeneration processes. In Narragansett Bay, Nixon et al. (1976) found a ratio of 21 and speculated that a considerable part of nitrogen was released as DON at the water-sediment interface. This ratio is known to increase in shallow-water sands when photosynthesis is important, stressing the role of benthic diatoms in nutrient cycling (up to 234 in Propp et al. 1981). In our experiment, the ratio reached 88 for muddy bottoms, 165 for grey-sand and 573 for white-sand, indicating a considerable increase of nitrogen depletion from muddy bottoms to white-sand bottoms.

In the tropics, regenerated ammonium should be the most important source of regenerated nitrogen. In the SW New Caledonia lagoon, the occurrence of lowerthan-predicted ammonium fluxes, when compared to oxygen consumption, could suggest that nitrogen might be lost via nitrification, possibly coupled to denitrification (Jenkins \& Kemp 1984). Indeed, nitrate fluxes were correlated with ammonium fluxes suggesting that some nitrification occurred, but they were too low to explain the deficiency of ammonium efflux from muddy and grey-sand bottoms. Nitrate uptake in white-sand bottoms could suggest some denitrification in the sediment fuelled by the water column. In other tropical areas, low or even no fluxes of regenerated nutrients have been recorded in enclosure experiments in spite of high benthic respiration reflecting high rates of nitrogen utilization by benthic communities (see Alongi 1989 for review).

Pelagic processes are known to be stimulated by contact with the benthos and intra-system transfers of ammonium within the reef have been suggested (Hopkinson et al. 1987). In ammonium-enriched water trapped in enclosures, an active uptake process was identified in the top layers of sediment by strong $\mathrm{NH}_{4}$ uptake against the sediment concentration gradient (Johnstone et al. 1989). A 'filter effect' has been attributed to a direct and indirect influence of microphytobenthos (Höpner \& Wonneberger 1985, Andersen \& Kristensen 1988, Sundbäck \& Granéli 1988) and/or of microbial processes (Boto et al. 1989), both acting as 
regulators of the nutrient flux between sediment and water. Microalgae (Dugdale \& Goering 1967) and multicellular marine algae (Ryther et al. 1981), that become nitrogen deficient during the day, are known to make up for the deficiency by assimilation of DIN in the dark. Symbiosis observed in many taxa (e.g corals, sponges, lamellibranches, polychaetes) seems to cope with a paucity of environmental nitrogen, retaining virtually all the dissolved nitrogen excretion from animals (Muscatine \& D'Elia 1978).

Nitrogen may be lost by reef release of mucus, planulae and free amino acids (Gerber \& Marshall 1974). Some enclosure experiments, where poisons were applied to sediment surface, have suggested a close coupling between DIN and/or DON fluxes and bacterial productivity in the tropical environment, bacteria being capable of utilizing amino acid flux or dissolved organic carbon flux to the sediment-water interface (Stanley et al. 1987, Boto et al. 1989). Recycling of organic matter through a dissolved organic pool, labelled as DON, may be an important pathway with different kinetic parameters in tropical and temperate marine environments (Nixon et al, 1976, La Roche \& Harrison 1987). Our results suggest DON efflux towards the water column in grey-sand bottoms (equivalent to ammonium release), but strong DON uptake in muddy bottoms and white-sand bottoms indicating considerable nitrogen demand from the sediment and suggesting utilization by a highly productive benthos.

Acknowledgements. This research was supported by a French grant INSU/ORSTOM 'AIP: Récifs coralliens' 88/50/N 5088. We thank the crew of OV 'Alis' for all their help at sea. We gratefully acknowledge the skilled assistance provided by ORSTOM center staff and particularly to Sylvain Bonnet, Philippe Gérard, and Pierre Laboute, who performed the nitrogen analyses and part of SCUBA diving sampling respectively. Special thanks are extended to Pascal Douillet who computed the multilinear regression program and to Richard Warwick (Plymouth Marine Lab.) for helpful criticism of the manuscript.

\section{LITERATURE CITED}

Alongi, D. M. (1987). The influence of mangrove-derived tannins on intertidal meiobenthos in tropical estuaries. Oecologia (Berl.) 71. 537-540

Alongi, D. M. (1988). Bacterial productivity and microbial biomass in tropical mangrove sediments. Microb. Ecol. 15: $59-79$

Alongi, D. M. (1989). The role of soft-bottom benthic communities in tropical mangrove and coral reef ecosystems Aquatic Sci. 1 (2): 243-280

Andersen, F. O., Hargrave, B. T (1984). Effects of Spartina detritus enrichment on aerobic/anaerobic benthic metabolism in an intertidal sediment. Mar. Ecol. Prog. Ser. 16: $161-171$
Andersen, F. O. Kristensen, E. (1988). The influence of macrofauna on estuarine benthic community metabolism: a microcosm study. Mar Biol. 99: 591-603

Armstrong, F. A. J., Tibbitts, S. (1968). Photochemical combustion of organic matter in sea water for nitrogen, phosphorus and carbon determination. J. mar. biol. Ass. U. K. 48: $143-152$

Bancroft, K. E., Paul, E. A., Wiebe, W. J. (1966). The extraction and measurement of adenosin-tri-phosphate from marine sediment. Limnol. Oceanogr. 21: 473-479

Banse, K. (1982). Mass-scaled rates of respiration and intrinsec growth in very small invertebrates. Mar. Ecol. Prog. Ser. 9. 281-297

Banse, K., Nichols, F. H., May, D. R. (1971). Oxygen consumption by the seabed. III. On the role of macrofauna at three stations. Vie Milieu, Suppl, 4: 17-26

Boto, K. G., Alongi, D. M., Nott, A. L. J. (1989). Dissolved organic carbon-bacteria interactions at sediment-water interface in a tropical mangrove system. Mar. Ecol. Prog. Ser. 51: 243-251

Boucher, G., Boucher-Rodoni, R. (1988). In situ measurement of respiratory metabolism and nitrogen fluxes at the interface of oysterbeds. Mar. Ecol. Prog. Ser 44: 229-238

Boucher-Rodoni, R., Boucher, G. (in press). In situ study of the effect of oyster biomass on benthic metabolic exchange rates. Hydrobiologia

Brown, B. E. (1987). Heavy metals pollution on coral reefs. In: Salvat B. (ed.) Human impacts on coral reefs: facts and recommendations, Antenne Museum E.P.H.E., French Polynesia, p. 119-134

Chardy, P., Chevillon, C., Clavier, J. (1988). Major benthic communities in the south west lagoon of New Caledonia. Coral Reefs $7 \cdot 69-75$

Chardy, P., Clavier, J. (1988a). Biomass and trophic structure of the macrobenthos in the South-West lagoon of New Caledonia. Mar Biol 99: 195-202

Chardy, P., Clavier, J. (1988b). An attempt to estimate the Carbon budget for the South West lagoon of New Caledonia. Proc. 6th. Int. Coral Reef Symp. 2: 541-546

Charpy-Roubaud, C. J. (1986). Le microphytobenthos du lagon de Tikehau (Polynésie française): II. Production primaire Notes Docums, océanogr. ORSTOM 28: 51-80

Clavier, J., Boucher, G., Bonnet, S., Gérard, P., Laboute, P., Di Matteo, A. (in press). Métabolisme aérobie du benthos et flux d'azote à l'interface eau-sédiment dans le lagon Sud-Ouest de Nouvelle Calédonie. Méthodes et recueil des données. Rapp. scient. Tech. ORSTOM Nouméa, Sci. Mer, Biol. Mar.

Crossland, C. J., Barnes, D. J. (1983). Dissolved nutrients and organic particulates in water flowing over coral reefs at Lizard Island. A.ust. J. mar. Freshwat. Res. 34: 835-844

Dale, N. G. (1974). Bacteria in intertidal sediments: factors related to their distribution. Limnol. Oceanogr. 19: $509-518$

Dugdale, R. C., Goering, J. J. (1967). Uptake of new and regenerated forms of nitrogen in primary productivity. Limnol. Oceanogr. 12: 196-206

Gerber, R. P., Marshall, N. (1974), Ingestion of detritus by lagoon pelagic community at Eniwetok Atoll. Limnol. Oceanogr. 19: 815-824

Gerlach, S. A., Hahn, A. E., Schrage, M. (1985). Size spectra of benthic biomass and metabolism. Mar. Ecol. Prog. Ser. 26: 161-173

Hartley, H. O. (1961). The modified Gauss-Newton method for the fitting of non-linear regression function by the least squares. Technometrics 3: 269-280

Heip, C., Vincx, M., Vranken, G. (1985). The ecology of marine nematodes. Oceanogr. mar. Biol. A. Rev. 2: 399-489 
Holm-Hansen, O., Pearl, H. W. (1972). The applicability of ATP determination for estimation of microbial biomass and metabolic activity. Mem. Ist. Ital. Idrobiol. 29 (Suppl.): $149-168$

Holm-Hansen, O., Riemann, B. (1978). Chlorophyll a determination: improvements in methodology. Oikos 30: 438-447

Hopkinson, C. S. Jr, Sherr, B. F., Ducklow, H. W (1987). Microbial regeneration in the water column of Davies Reef, Australia. Mar. Ecol. Prog. Ser. 41. 147-153

Höner, T., Wonneberger, K. (1985). Examination of connexion between the patchiness of benthic nutrient efflux and epiphytobenthos patchiness on intertidal flats. Neth. J. Sea Res. $19(3 / 4): 277-285$

Jansson, B. (1967). The significance of grain size and porewater content for the intertitial fauna of sandy beaches. Oikos 18: 311-322

Jenkins, M. C., Kemp, W M., Jr (1984). The coupling of nitrification and denitrification in two estuarine sediments. Limnol. Oceanogr. 29: 609-619

Johannes, R. E, and Project Symbios Team (1972). The metabolism of some coral reef communities: a team study of nutrient and energy flux at Eniwetak. BioScience 22: $541-543$

Johnstone, R., Koop, K., Larkum, A. W. D. (1989). Fluxes of inorganic nitrogen between sediments and water in a coral reef lagoon. Proc. Linn. Soc. N.S.W 110 (3): 219-227

Karl, D. M., Larock, P. A. (1975). Adenosine triphosphate measurements in soil and marine sediments. J. Fish. Bd Can. 32: 599-607

Kemp, W. M., Boyton, W. R. (1981). External and internal factors regulating metabolic rates of an estuarine community. Oecologia (Berl.) 51: 19-27

Kinsey, D. W (1985). The functional role of back-reef and lagoonal systems in the Central Great Barrier Reef. Proc. Sth int. Coral Reef Congr. Tahiti 6: 223-228

LaRoche, J., Harrison, W. G. (1987). Compartmental models of nitrogen cycling in tropical and temperate marine environments. Mar. Ecol. Prog. Ser 38: 137-149

Lawton, W. H., Sylvestre, E. A. (1971). Elimination of linear parameters in non-linear regression. Technometrics 13: $461-467$

Lewis, J. B. (1977). Processes of organic production on coral reefs. Biol. Rev. 52: 305-347

Marshall, N. (1965). Detritus over the reef and its potential contribution to adjacent waters of Eniwetok Atoll. Ecology 46: 343-344

Muscatine, L., D'Elia, C. F. (1978). The uptake, retention and release of ammonium by reef corals, Limnol. Oceanogr. 23 (4): $725-734$

Nixon, S. W., Oviatt, C. A., Hale, S. S. (1976). Nitrogen regeneration and the metabolism of coastal marine bottom communities. In. Anderson, J. M., Macfadyen, A. (eds.) The role of terrestrial and aquatic organisms in decomposition processes. Blackwell Sci. Publ. Oxford, p. 269-283

Nowicki, B. L., Nixon, S. W (1985). Benthic community metabolism in a coastal lagoon ecosystem. Mar. Ecol. Prog. Ser. 22: 21-30

Pamatmat, M. M. (1977). Benthic community metabolism: a review and assessment of present status and outlook. In Coull, B. C. (ed.) Ecology of marine benthos. Belle W. Baruch Library in Marine Science. Univ. South Carolina Press Columbia, p. 89-111
Pamatmat, M. M., Findlay, S. (1983). Metabolism of microbes, nematodes, polychaetes, and their interactions in sediments, as detected by heat flow measurements. Mar. Ecol. Prog. Ser. 11. 31-38

Pomroy, A. J., Joint, I. R. Clarke, K. R. (1983). Benthic nutrient flux in a shallow coastal environment. Oecologia (Berl.) 60: 306-312

Propp, M. V., Tarasoff, V G., Cherbadgi, I. I., Lootzik, N. V (1981). Benthic-pelagic oxygen and nutrient exchange in a coastal region of the sea of Japan. In: Tenore, K., Coull, B. C. (eds.) Marine benthic dynamics. Belle W Baruch Library in Marine Science, University South Carolina press, Columbia, p. 265-284

Redfield, A. C. (1934). On the proportions of organic derivatives in sea water and their relation to the composition of plankton. In: James Johnstone Memorial Volume, University Press, Liverpool, p. 177-192

Rhyther, J. H., Corwin, N., DeBusk, T. A., Williams, L. D. (1981). Nitrogen uptake and storage by the red alga Gracilaria tikvahiae (McLachlan, 1979). Aquaculture 26 : $107-115$

Richer de Forges, B., Barbigant, G., Menou, J. L., Garrigue, C. (1987). La lagon Sud-Ouest de la Nouvelle Calédonie. Oberservations préalables à la cartographie bionomique des fonds meubles. Rapp. scient. tech. ORSTOM/Nouméa 45: $110 \mathrm{pp}$.

Rougerie, F., Wauthy, B. (1986). Le concept d'endo-upwelling dans le fonctionnement des atolls-oasis. Oceanologica acta 9 (2): $133-148$

Sikora, J. P., Sikora, W. B., Erkenbrecher, C. W., Coull, B. C. (1977). Significance of ATP, carbon, and caloric content of meiobenthic nematodes in partitioning biomass. Mar. Biol. 44: 7-14

Smith, K. L., Jr (1971). Respiration of a sublittoral community Ecology 54: 1065-1075

Smith, S. V. (1984). Phosphorus versus nitrogen limitation in the marine environment. Limnol. Oceanogr. 29: 1149-1160

Solorzano, L. (1969). Determination of ammonia in natural waters by the phenylhypochlorite method. Limnol. Oceanogr. 14: 799-801

Sorokin, Y I. (1973). Role of microorganisms in the metabolism and productivity of Hawailan reefs. Oceanology 13: 262-267

Soumia, A. (1976). Oxygen metabolism of a fringing reef in French Polynesia. Helgoländer wiss. Meeresunters. 28: $401-410$

Stanley, S. O., Boto, K. G., Alongi, D. M., Gillian, F. T. (1987) Composition and bacterial utilization of free amino acids in tropical mangrove sediments. Mar Chem. 22: 13-30

Steele, J. H. (1974). The structure of marine ecosystems. Harvard Univ. Press, Cambridge, Mass.

Sundbäck, K. Granéli, W. (1988). Influence of microphytobenthos on the nutrient flux between sediment and water a laboratory study. Mar Ecol. Prog. Ser. 43: 63-69

Treguer, P., LeCorre, P. (1975). Manuel d'analyse des sels nutritifs dans l'eau de mer (utilisation de l'autoanalyseur Technicon IIR), 2e éd. Univ. Bretagne Occidentale, Brest

Wiebe, W J. (1985). Nitrogen dynamics on coral reefs. Proc. 5th Int. Coral Reef Congr., Tahiti 3: 401-40S

Wiebe, W J., Johannes, R. E., Webb, K. L. (12975). Nitrogen fixation in coral reef community. Science 188: $257-259$

Manuscript first received: December 5, 1989

Revised version accepted: March 26, 1990 